CATALAN REVIEW

Catalan Review

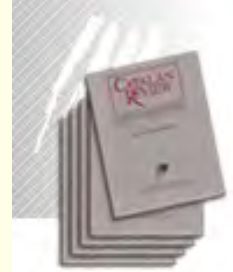

You are accessing the Digital Archive of the Catalan Review Journal.

By accessing and/or using this Digital Archive, you accept and agree to abide by the Terms and Conditions of Use available at http://www.nacs-

catalanstudies.org/catalan review.html

Catalan Review is the premier international scholarly journal devoted to all aspects of Catalan culture. By Catalan culture is understood all manifestations of intellectual and artistic life produced in the Catalan language or in the geographical areas where Catalan is spoken. Catalan Review has been in publication since 1986.
NORTH

AMERICAN

CATALAN

SOCIETY
Esteu accedint a l'Arxiu Digital del Catalan Review

A l' accedir i / o utilitzar aquest Arxiu Digital, vostè accepta i es compromet a complir els termes i condicions d'ús disponibles a http://www.nacs-

catalanstudies.org/catalan review.html

Catalan Review és la primera revista internacional dedicada a tots els aspectes de la cultura catalana. Per la cultura catalana s'entén totes les manifestacions de la vida intel lectual i artística produïda en llengua catalana o en les zones geogràfiques on es parla català. Catalan Review es publica des de 1986.

\title{
The Late Realist Novel and Art-Horror: Marià Vayreda's La punyalada and the Question of Genre Timothy McGovern
}

Catalan Review, Vol. XV, No. 2 (2001), p. 115-136+ 


\section{THE LATE REALIST NOVEL AND ART-HORROR: \\ MARIÀ VAYREDA'S LA PUNYALADA AND THE QUESTION OF GENRE}

\section{TIMOTHY McGOVERN}

Marià Vayreda's novel La punyalada (1902-3) ends with the protagonist's confession that he has regained his sanity, that a tumor which infected him with evil has been cut from his body, and that he may or may not now be lying in his lover's arms, the same lover who had only just stabbed him: "Després una veu que a cau d'orella em cridava pel meu nom; i, com en somnis, una rosada de gotes tèbies que em queia damunt de la cara, i sobre el front el pessigolleig d'uns llavis com de mare amorosa; i després... res més" (585).

This is both the end and the beginning of the problematic interpretation of this novel, considered one of the most important Catalan novels of the Nincteenth and early Twentieth Centuries, even more problematic in the light of Vayreda's only other novel Sang nova (1900) which is an essentially romantic tale encouraging a modern approach to Catalan nationalism. Superficially, the only obvious connection between the two works is the use of the word "sang" (blood); in the one case it denotes a new generation (new blood), while in the closing to the prologue of La punyalada, the narrator uses the term to mean gore to be feared by the public: "és molta sang, potser massa per aquests temps de refinaments i de feminisme" (Vayreda 46I). . However, upon closer examination, the use of gore and blood may reveal the same, albeit underlying, nationalistic intention, that is seen in Sang nova. Vayreda wrote

I The entire passage in fact warns of the gore which will be presented. The narrator warns the scribe to take care in the presentation of the novel in a manner similar to that found in the prologue to Victor Català's Drames rurals (1902) in that both narrators state that their work will be too graphic for the modern reader (Català 249). However, while Caterina Albert i Paradis' short stories present tales of madness and death, they do not attempt to shock the reader with the gore presented in this novel. Vayreda's repetition of the image of bloodiness and the warning resemble the trailers to modern films of horror or suspense and their advice to the audience that "this film may be too intense, terrifying, or extreme, for some viewers:

Per la resta, vostres són: talleu i cosiu a vostre albir; mes, per si tinguéssiu la pensada de donar al públic aquestes pàgines, mediteu bé si fóra millor encara llençar-les al foc. Estan tan plenes de sang!... Sang brollada a dolls d'amples ferides, i sang d'aquella que regalima a gotes d'un cor llatzerat per la desesperació i les sequedats de l'esperit, i... és molta sang, potser massa per aquests témps de refinaments i de feminisme. Amb tot, heu's-les aquí, i dones en sou advertit, si no us plauen, cremeu-les i fareu millor (Vayreda 46r) 
numerous political articles in the journal $L^{\prime}$ Olot $i$ against centralism and those he perceived as progressives who adopted centralist and/or federalist politics, following a French and therefore foreign model. His 1892 article "Regionalisme" presents a scathing attack on centralist ideology, and ends with a defiant defense of his conservative regionalism, and its basis in history and reason: "Nosaltres som tradicionalistes, en el ver sentit de la paraula; és a dir, partidaris del dret històric i de l'experiència racional; amics de l'autoritat consolidada, sense ésser per això enemics de l'avenç legítim. Preferim mil voltes el nom de retrògrades que ens donen els sequaços d'en $\mathrm{Pi}$ (Francesc $\mathrm{Pi}$ i Margall), al de progressistes avançats que ells tan pomposament s'irroguen (Obres 59I). This article, and later in 1893 , his attack on "La Justícia a Espanya", both show his strong mistrust/disillusionment with the federalists, in fact a distrust of all that which comes from without.

Fear-inspiring literature, that which belongs to the overlapping genres of the Gothic, Art-Horror, and Terror-Inspiring, is more than simply fear-inspiring; the fear must be rooted in some fear that the reader knows or whose existences is at least suspected. This fear may be that of a new acceptance of sensuality/sexuality (as seen in the gothic), fear of technology (in science fiction horror), or fear of the Other, either other political ideologies (Communism during the cold war), or of other races and cultures (aliens and monsters from the depths of the earth and ocean). It is this presentation of a terrorinspiring text that the present study will examine in order to not only analyze why and where to designate a novel filled with repulsive scenes, but also to point to the underlying themes which a superficial terror tends to belie.

The presence of fear is a major theme in Catalan Modernism, primarily in rural literature. If Garrotxa, the mountain village in which the action transpires, is presented as a magnet for deviants and violence, is this not the case in Victor Català's Drames rurals and Solitud, and in Raimon Casellas' Les Multituds and Els sots feréstecs? Anima, the animalistic murderer in Solitud is different from the vicious Ivo of Vayreda's novel only in his intensity and capacity for mass murder, while the condemned criminal from Casellas' story "Dia de sentència" as well as the grape pickers (also from the mountains) from the story "Les veremes de la por" could all be members of Ivo's gang. Joan-Lluis Marfany, in Aspectes del modernisme, considers this violence and the presentation of "subhuman" characters typical to Catalan Modernisme: "La literatura modernista de tema rural no idealitza el pagès, al contrari: el pagès és la rutina, l'hostilitat a tot el que és nou, la submissió cega, estúpida, fanàtica, a velles supersticions a tradicions opressives, a atavismes 
animals, la dependència esclava d'un monstruós sentiment de la propietat i les deficiències morals que se'n deriven, avarícia, egoisme, mesquinesa" (195). The presentation of the "monstrous" is not simply gratuitous in any of these works, including La punyalada, and if Vayreda differed from many of his contemporaries in that he was a conservative, he was still a conservative proponent of "Catalanisme", and fearful not only of a fanatical ignorance, but also of the new evils of outside forces exerting their influence on Catalonia.

The narrative structure of La punyalada raises questions, questions which the text cannot or will not answer. The "res més", or "nothing else/more" with which the novel ends would suppose that the narrator Albert del Cortals dies from the wound inflicted upon him by his lover Coralí, especially as "res més" has already been used to signify death in the novel when the narrator uses the same expression in an almost identical context to express the death of Ivo, Albert's enemy. This scene is one of the many graphic scenes of death in the novel which depict the terror of the soon-to-die in a voyeuristic manner, the same which attracts modern audiences to films presenting the gory deaths of victims in films ranging from those of horror and action-suspense to the snuff films of decades past: "A poc sentí als polsos el refrec d'un canó de fusell que s'introduí en la boca bleixant del meu enemic; després, un retrò que feia esclatar queicom com si fos un carabassot podrit, semblant-me que era el meu propi cervell que es desfeia amb un xarbot de fang; després...res més...el meu ser quedà desfet, com engolit per les tenebres del no-res" (579). However, the "res més" at the end of the narrative, and indeed the entire narrative except for the introduction, is the collection of memoirs of the now deranged (or perhaps not) hermit (Narrator ${ }_{2}$ ) who writes the story of his fortunes and sends them in as a mysterious manuscript to the compiler (Narrator) who has traversed the mountains of Catalonia searching for folk tales. Is Albert's death a spiritual one, the metaphorical death of his own madness, or is this simply the end of the story that he relates to the editor who presents his story? A further problem is that Vayreda was only able to revise the first nine chapters of the text before his death, adding the character of the editor/compiler (Riquer 536). In the original version, published in serial form in La Ilustració Catalana in I902, Albert is the only narrator, therefore his death, that of the "nothing more" for a narrator would, at least textually, indicate his death.

La punyalada presents aspects of the folktale in its mythical setting in the village of the damned, it is definitely a psychological study into Albert's weakness of character which leads to his descent into madness, many of the descriptions of the relationship between the characters and their environment and the problematic ending 
fulfil characteristics of grotesque or horrifying fantastic literature, and the graphic scenes of mutilation and gory presentations of death, which shock more than sadden, cause the novel to approach the genres of terror and/or horror mass fiction and film. Some of the more shocking passages describing corpses (and those soon to be) may be mirrored in modern horror and slasher films, but instead of only briefly presenting the ghastly image to the spectator, these are presented slowly, and in graphic detail. The purpose of this study is to analyze the different narrative components of this novel, a novel which both fits into, and yet defies, many descriptions of genre, in order to test the modern definitions of the "dark genres" (art-horror, terror-inspiring art, and the gothic romance) to relate these otherworldly genres to the real world political and social issues that they criticize.

On a symbolic level, the love/hate triangle formed by the three main characters can be analyzed according to Freud's theory of the Oedipus Complex. The very case of the triangle is documented in the relatively few studies concerning this work. The critic Antònia Tayadella i Oller in "La novel-la realista", first notes the strangeness of this work which defies categorization: " $L$ a punyalada, la millor obra de Marià Vayreda, és una novel-la ben peculiar en el marc de la narrativa catalana vuitcentista, atesa la seva qualitat i, sobretot, l'aprofundiment en el terreny de l'anàlisi psicològica, veritable punt feble de tota la narrativa catalana del segle XIX" (Riquer 536). This is typical of studies which mention the novel in that its peculiarity is mentioned, but not analyzed in detail. However, the triangle, which will be studied here in Freudian terms, is also identified in Tayadella i Oller's study: "La punyalada presenta, en principi, una història de passions desfermades i ferotges, articulada al voltant d'una estructura triangular de personatges, entre els quals s'estableixen una sèrie de relacions d'atracció i de rebuig" (536).

This triangle and the environment in which it exists, the mountainous region of Garrotxa, quickly take on a mythical presence in the novel and the triangle itself begins to fit into the descriptions of the Oedipal triangle and the theories of the totem and taboos presented in Freud's Totem and Taboo (1913). While the setting of the novel begins simply as a town in the mountains of Catalonia whose inhabitants suffer terror at the hands of bands of bandits and kidnappers, ${ }^{2}$ this environment quickly is transformed into a Catalan

2 The use of the "gang of bandits or criminals" in the novel is one of the first elements which relate it to other works in which violence and/or terror are the central themes or catalysts for action. This can be scen from the time cf Manzoni's Promessi sposi to the more modern works of group evildoers such as the mafia in Puzo's The Godfather and contemporary low brow movies (and television productions) concerning the terror 
Village of the Damned (again a mythical realm relating back to the condemned city of Sodom). In the opening scene of the novel, Mossèn Jeroni, the village priest, gives a sermon first lamenting the mutilation of various parishioners by the trabucaires (the bands of murdering thieves), ${ }^{3}$ and then stating the reason that the bandits are drawn to the town: "¿Sabeu per què vénen ací? No és pas sols perquè hi troben amagatalls, vores i boscúries que els posen a cobert de la justícia humana, no; és perquè aquí hi troben gent tan dolenta com ells, perquè vosaltres teniu el cor més dur que les roques d'aquestes cingleres, perquè vosaltres, que professeu aquell maleit refrany que diu: "La carn que no es cou per tu deixar-la cremar"..." (464). The priest's words apparently affect the townspeople, at least in the moment that they are uttered, but upon leaving the church they immediately forget his reprimand and fall into a frenzy of dancing and drinking, forgetful of his message condemning their "sinfulness". He warns them again of their fate and compares the town to Israel in the Old Testament, punished by God and abandoned to their enemies. The villagers, however, do not heed his warning and the description of their party, and the sexual element evoked by the presence of the Frenchmen, is described with the air of an approaching orgy: "En quant a les mosses, si bé totes es mostraven afligides i malmirroses, era de témer que no desitjaven sinó que ells les obliguessin a trencar els escrúpols... per força" (467). While this attack upon the women and their sexual needs is quite chauvinistic, it also demonstrates the total corruption of the village. This is an environment in which even the most horrible taboos have become attractive, even desired. The fact that it is the woman who maintains the moral reputation historically in Iberian society in the tradition of "honra", their desire to be dishonored, violated, and for their entire families to be symbolically violated, only further shows Garrotxa to be a mythical environment and its inhabitants a fallen race. This novel

produced by gangs. Concerning the graphic violence and the vigilante mentality of the townspeople and Albert, one may think of the novel's modern counterpart, the violent film of action and suspense, such as those starring Charles Bronson, the most obvious example being Death Wish I, II, etc.

3 This sermon is also the first graphic reference to the defilement of the body (mutilation being a theme in the novel and an obvious taboo for the characters) when Mossèn Jeroni tells of the fate of a villager kidnapped by the bandits. This is also the first use overt use of the word "horror" in the novel, which does not express the natural fear of death, but of torture, of defilement and the fear of impending danger. Warnings and prenarrative rales of this sort are common in the modern slasher film, used, for example in both the film Halloween and in the first of the Friday the $13^{\text {th }}$ series: "Pocs mesos fa de la troballa del cos botxinejat de l'infelię Barnol de Riudellots, sense orelles, sense ulls i sense dents, que els malvats li anaren arrencant per a fer-ne present a la seva familia que no podia pagar el seu rescat. Dels horrors comesos amb les dones del mas Rabassa i altres, més en sabeu vosaltres que jo" (Vayreda 464). 
calls for a return to the morality of a region far removed from Garrot-

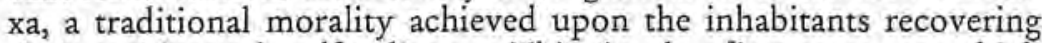
their pride and self-reliance. This is the first passage which demonstrates the underlying nationalism of the novel. Just as the characters in Sang nova discover their own Catalan nationalism and are renewed, so must those in La punyalada learn to be proud of their heritage and to reject outside influence and abandon their hopes for protection from the bandits by the central government. The Catalan inhabitants themselves must join together and fight against the invading forces (just as Manzoni presented the Spanish bandits in I promessi sposi in order to encourage the Italians to unite and fight against the foreign invader).

Ironically, the call to pleasure and for the rejection of the priest's sermon is given by Ivo, Albert's lifelong friend and his father-figure. Ivo is presented as a priest professing a reckless abandonment to immediate pleasure (or the antithesis of the priest's concerns which are historical in nature) at the beginning of the novel. He ridicules the priest's words and the crowd follows him, forgetting the atrocities that have thus been committed, accepting his invitation to merriment. The town, and in its isolation from any other society it takes on a distinctly tribal characteristic, has chosen its new leader and will follow him until he begins to feed on his own followers. Freud in Totem and Taboo states that tribal group will, at some point, abandon their priestly spiritual leaders and follow "inferior but practical persons, who were ready to renounce the honours of kingship" (60). These "honors" are the avoidance of sacred taboos and Ivo is the very creator and lover of the mutilation, death, and defilement of the body that the priest and also the town holds as taboo (and holds in horror) to this point. Ivo fits the mold of the post-spiritual ruler which rises, in Freud's interpretation of Society, after the priest limits his rule to the realm of the spiritual. Ivo may ignore exactly the same taboo prohibitions imposed upon others and realize the sexually ruthless, and also bloodthirsty, urges that the normal citizen would find unthinkable due to society's norms.

However, Freud also states that the ruler of this sort must be mistrusted by his followers and at some point they will have to attack or kill him. This hostility, or ambivalence between admiration and hate, is presented in the novel through the relationship between Ivo and Albert. Albert admires Ivo even though the bandit has led him into a life of crime and numerous close calls the law. So begins his mistrust of his "leader" but it is this very elevation of Ivo in Albert's mind to that of an idol that will set the stage for their later battle to the death.

Ivo is a father-figure for the fatherless Albert, and for Freud the 
shift from leader to father is predicted in psychoanalysis because children attribute the same powers or superiority to their fathers that a tribe does to its leader. If the maximum enemy to be feared is the father, for the followers of Freud, the paranoiac's elevation of their imagined enemies is the recreation of the Oedipal complex's hate of the father-figure or superior, supposedly now possessing superior cunning or power, for he is now the ultimate enemy and cause of all failure. 4

Ivo becomes an obsession for Albert in the novel and Albert blames his ex-friend for having completely destroyed the possibility of his achieving any sort of peace. In this work, Ivo becomes the father in the Oedipus triangle within a tribal totemic system. In Patrick Mullahy's Oedipus Myth and Complex, Freud's totality of the Oedipus complex is presented: A powerful father (the patriarch) both possesses sexually and rules politically the women of an extended family while exiling his sons whom he views as his rivals. The sons must hate their oppressor who is the source of their imposed celibacy in exile, and, upon invading the mythic patriarchal home, kill the father and find themselves victims of a powerful guilt arising from the fact that they also admired the father (Mullahy 66 ). The entire system is mirrored in the triangle as Coralí, Albert's betrothed, was also approached by Ivo. When Albert attacks Ivo in a fit of jealousy (even though he is conscious of his inferiority to the murderer) Ivo soon leaves the village and becomes a full blown bandit and murderer. Albert has contributed to the social death of the father-figure who had threatened to separate him from the woman he loves, and in fact, Ivo does separate them when he kidnaps Coralí, while Albert's dementia later causes him to despise her yet love her in an obsessive state of love/hate which Freud calls ambivalence. In the case of the totemic system, the sons must give up the women that they have killed their father in order to enjoy sexually out of guilt, and thus arises the incest taboo. In the case of Albert, when he has finally killed Ivo, there is a subconscious block to his loving Corali.

Coralí can also be considered a mother/sister figure in the novel. First, she is the daughter of the miller, the female miller often being characterized in European culture as the mother of a village in that

4 In Totem and Taboo, Freud presents this elevation of the enemy to superhuman status thus:

The model upon which paranoiacs base their delusions of persecution is the relation of a child to his father.. A son's picture of his father is habitually clothed with excessive powers of this kind, and it is found that distrust of the father is intimately linked with the admiration for him. When a paranoiac turns the figure of one of his associates into a 'persecutor', he is raising him to the rank of a father: he is putting him into a position in which he can blame him for all of his misfortunes (63). 
she is the source of the life-giving bread. Second, she belongs to the throwback totemic atmosphere of the village. The women in totemic society must not marry the men of their totem due to the extended incest taboo and this, in part would, explain the wish for the young women of the town to hope for sexual encounters with the visitors in the celebration.

The final aspect with regard to totemism to be analyzed here is Albert's positive totemism which materializes during one of his descents into insanity presented through his psychological transformation into a dog. The transformation which occurs here itself accelerates the novel's oscillation between genres, and the dogman narrator's tale now may belong either to the grotesque or the uncanny. Freud describes positive totemism as an obsession with a taboo animal or object to the point that the subject totally identifies with it, even wishing to become themselves a realization of the taboo object. His case is that of the child Arpád who is terrorized by a chicken and then psychologically becomes one, even as he finds the utmost pleasure in the slaughter of other chickens. ${ }^{5}$ Albert's transformation into a dog is a case similar to that of the wolfman, and at one point his "master" Rafel threatens to send him to an insane asylum due to his wolfman-like behavior: "Si em promets fer bondat i no fer més bestieses, vindràs amb mi; però si tornes, com abans, a rodar pels boscos com un llop...et portaré on no veuràs més el sol, t'ho juro" (573). ${ }^{6}$ Albert's mental state deteriorates to the point that he becomes/ believes himself to have become a dog, a symbol of his believed inferiority to Ivo. However, he is the fierce mastiff that his now master once owned and which was caged just as is Albert at the moment of his transformation. His initial transformation is very similar to that of the child in Freud's study in that he becomes fixed upon an animal,

5 Freud's case of positive totemism, while perhaps considered preposterous today, does lend itself to the study of the genre of terror and horror, especially the study of the wolfman who is so torally obsessed with the wolf he fears that he becomes the wolf. However, Freud's case deals with a chicken:

When little Árpád was two and a half years old, he had once, while he was on summer holiday, tried to micturate into the fowl-house and a fowl had bitten or snapped ar his penis. A year later, when he was back in the same place, he himself turned into a fowl; his one interest was in the fowl-house and in what went on there and he abandoned human speech in favour of cackling and crowing (Freud $16_{3}$ ).

6 Albert's transformation in dog is discussed at length in the critic Maurici Serrahima's Dotze mestres. What is interesting in both the novel and Serrahima's study is that Albert is treated as if he truly had physically transformed into a canine: "El que inicialment semblava una metảfora s'hi converteix gairebé en descripció d'una realitat, subratllada per un seguit de detalls esborronadors; entre altres, la manera com l'Albert, reclòs en un corral, després d'un incident de bogeria que ell ni tan sols no recorda, rep Rafel, quan obre la porta, amb "un esclat de joia verament bestial", com el d'un gos" (Serrahima n6). 
perhaps a feared animal, from his past. 7 The animal which he has become will be the source of his revenge against Ivo. He has become Rafel's mastiff which was a terror to the wolves and he will become a terror to Ivo and just as Rafel led his dog to the hunt, he will later lead Albert to the camp where Ivo hides so that he may kill him.

Freud's positive totemism subject, the child Árpád, rejoices in the imaginary killing of his obsession: "His favourite game was playing slaughtering fowls. The slaughtering of poultry was a regular festival for him. He would dance round the animals' bodies for hours at a time in a state of intense excitement" ( 162$)$. However, the same child later reveals that he associates the fowl with his father, and it is the idea of his own father's death that he is celebrating. Likewise, Albert, who just previous to his transformation into a dog behaved like a wolf, now must destroy the wolf (now the father-figure Ivo). Albert attacks Ivo as a dog attacks the wolf, and kills him by gnawing his throat: "Aviat vaig poder aferrussar-me-li al coll, començant a rosegar-li la carn amb una força inconcebible: em sentia més gos que mai, i l'esfrimolar sentre les meves dents aquella carnassa dura com sola em produia una sensació de plaer intensa enterament pròpia de les bèsties (579). Just as Freud's subject wishes to kill his father (projected as a fowl) so that he may take over his role as the malefowl, Albert, as a beast, kills the beast who is the totem father so that he may be the dominant male. This dog-like gnawing of his fatherfigure only further forces the novel into an Oedipal context because of its presentation of a cannibalistic destruction of the father at the hands of the sexually-deprived son, an event paralleling the origin of the Oedipus complex and the incest taboo. In the Freudian interpretation of the Oedipus Myth origin, this cannibalism is realized in order for the sons to partake of the father's strength, to become a part of him, while in La punyalada Albert regresses even further into a mythical past in his cannibalism. He is already part of a mythical tribe, in his attack he travels to the very "bestial" past of humankind. His final revenge is based totally upon instinct, and he has abandoned the realm of the human for that of pure impulse, just as this novel achieves its impact through its use of scenes which cause reactions of revulsion or terror on the part of the reader.

7 Albert remembers the day of his cransformation thus:

En altre temps, tenia en Rafel un mastí famós com no n'hi havia d'altre en tota la muntanya per a fer cara al llop. Era un animalàs feréstec, que a penes reconeixia altre amo que el propi Rafel, al que estava adherit com un esclau mimat...Ara bé: el meu captiveri i aquella retxa em portaren a la memòria el mastí captiu com jo, i aquella idea s'anà infiltrant de tal manera en el meu pobre cervell malalt i incapaç de coordinar idees, que vaig acabar per identificar-me amb el record d'aquella bèstia de tal manera com si fos ella mateixa (Vayreda 572 ). 
The first genre with which La punyalada may be associated, after that of the horrific "novela de folletín" popularized by Fernández y González and others, is the Gothic romance. ${ }^{8}$ The exact definition of this genre is also elusive. The one concrete point which contemporary studies concerning the Gothic as genre agree, is its point of origin in Walpole's The Castle of Oltranto ( 1764 ) while the Gothic canon varies immensely depending upon the national literature studied by the critic. ${ }^{9}$ However, the "definition" of the Gothic which will be used here will be a composite, based upon the book length studies on the Gothic genre by Elizabeth MacAndrew, William Patrick Day, and Linda Bayer-Berenbaum, as well as Wolfgang Kayser's study of the grotesque due to rather constant reference to the grotesque in studies on gothic literature and Kayser's own references to the gothic in his work on the Grotesque. ${ }^{10}$ Indeed works concerning the tale of terror, works which are grotesque, and those belonging to the Gothic are interchangeable in a large corpus of the studies on these genres.

The term grotesque is recurring in studies on Gothic fiction, and

8 One may think of the serial novels (and those produced by ghost writers) which were "written" by Manuel Fernández y González, such as Las brujas de Madrid, and Agustín Pérez Zaragoza's Galeria fuinebre de espectros y sombras ensangrentadas, as well as similar works dealing with murderers, fiends, and ghosts by Ayguals de Izco and Pérez Escrich.

9 The number of works which may at least present Gothic traits is enormous. One may think in England of the obvious: Wilkie Collins, Anne Radcliffe, and countless others, and even Dickens creates a Gothic atmosphere in Bleak House and The Mystery of Edwin Drood, as well as in scenes from The Pickwick Papers and other works. In Portugal, Almeida Garretr's O Arco de Sant'Anna and many of Camilo Castelo Branco's novels (such as $O$ Esqueleto) share elements of nocturnal and mysterious elements, as well as a focus on decay. Perhaps the most famous Gothic novel in Nineteenth Century Italy is Antonio Fogazzaro's Malombra, a work which presents madness, the possible presence of a ghost, the mansion, the importance of night, and a mysterious murder. In Spain, besides the definitely Gothic elements found in Bécquer's legends, one may include many of the romantic historical novels, and there exists at least a gothic air of mystery (and the presence of the almost requisite mysterious mansion) in Galdós' La sombra. The reader may still explore Germany, France, and the Americas and find at least cases of gothic elements in each.

to Regardless of the minor differences in the definitions of the Gothic novel, a consensus arises regarding mood or atmosphere upon closer inspection. The Gothic romance Elizabeth MacAndrew has decided that "Gothic fiction gives shape to the place of evil in the human mind" (3), William Patrick Day describes the Gothic thus: "The Gothic world is one of unresolved chaos of continuous transformation, of cruelty and fear, of the monstruous that is the shadow and mockery of human" (8). Linda Bayer-Berenbaum begins her study of the Gothic form by stating:

The Gothic setting first introduces the expanded domain by insinuating that reality may be higher and deeper and more tangled than we ordinarily think. Persistent contrasts illustrate this greater scope. The Gothic landscape plunges from extreme to extreme: from the height of an airy bell tower to the depth of a dungeon wall... Even modern Gothic novels that have abandoned these clichés still maintain extreme contrast (22). 
likewise Kayser's study makes many references to the Gothic novel. Most important to this study is the placement of much of Edgar Allen Poe's works (one may think of The Fall of the House of Usher) as Gothic works while Kayser calls Poe's technique grotesque: "The distortion of all ingredients, the fusion of different realms, the coexistence of beautiful, bizarre, ghastly, and repulsive elements, the merger of the parts into a turbulent whole, the withdrawal into a phantasmagoric and nocturnal world (Poe used to speak of his "daydreams") - all these features have here entered into the concept of the grotesque" (Kayser 79).

The premise here is that Gothic literature is the forerunner of modern terror-inspiring or art-horror literature. The Gothic novel presents a dream/nightmare world in which there is evil being planned or committed by either madmen or supernatural forces. La punyalada, while lacking the castle and spiral staircase so often associated with the Gothic tradition, still presents the same basic symbols which pervade the traditional Gothic novel: the presentation of contrasts (beautiful/ghastly), the melting of the distinction between reality and the dreamworld, the definite presence of the night as a time which distorts the perception of reality and hides imminent dangers, and lastly, the constantly lingering presence of death.

Garrotxa as a narrative space has already been shown to be a mythical village of the damned, a place which attracts and gives birth to evil. However, the prologue to La punyalada sets the book in the context of the Gothic novel from its beginnings with the presentation of a mysterious manuscript which the compiler presents to his public, immediately establishing a tone of mystery itself, just as in the Castle of Otranto. ${ }^{\text {II }}$ The implied reader is thus made to withhold judgement of the text, as the editor cannot be blamed for either the presentation of gruesome (immoral?) details or for the presentation of the bizarre events that contradict the rational approach which the realist author must follow in a modern society based upon science and the observation of reality. Justly so, in the revision, albeit incomplete, of La punyalada, Vayreda adds the traditional prologue which discusses the presentation of the manuscript, written by the bizarre hermit Albert, after his death:

Passaren molts mesos, i quan ja em preparava per a reanudar les meves excursions anyals, rebí la visita d'un subjecte que es digué marmessor de l'Albert dels Bardals, qui, després de fer-me saber la mort d'aquest, manifestà que entre

II Elizabeth MacAndrew considers this to be essential to the creation of the Gothic atmosphere: "The first Gothic characteristic of Otranto is its presentation as an ancient manuscript rediscovered. This produces an indirect, mediated narration that imparts an air of strangeness to the exotic setting" (10). 
els seus papers s'havia trobat un paquet clos adreçat al meu nom; pel que creia interpretar la voluntat del difunt fent-me'l a mans (459).

While La punyalada differs from earlier Gothic novels in that it was written after the realist's, and especially the naturalist Zola's, insistence upon faithfully presenting contemporary reality, the effect is the same for the work escapes its contemporary intellectual context. ${ }^{12}$ Disbelief in the text itself and criticism of the author's approach must be suspended, and in this manner Vayreda (or the implied author at least) could present a work set far from the realm presented by his Naturalist contemporaries. This same literary proposal is seen in Antonio Fogazzaro's Malombra, the Italian writer himself having followed the Verists then writing a Gothic romance in which the female protagonist is apparently possessed by a dead soul.

William Patrick Day, in his study In the Circles of Fear and Desire, sets forth the characteristics of the Gothic protagonist, both male and female. According to Day, and he also bases his definitions on Walpole's novel as well as others:

they are incapable of effective action... The hero is usually engaged in furious action, but this gets him no farther than passivity does his Gothic sister. However hard Ambrosio the Monk seeks pleasure and power, he acts only in ways that lead to his damnation. This is true of all Gothic heroes; even those who appear to have achieved what they desire are only marking time, moving a circle that leads to their destruction (Day 18).

This is seemingly a description of Albert's trajectory in the novel, $\mathrm{He}$ is engaged in a furious spiral action within the novel, searching the mountains for the kidnapped Corali in a quest for revenge against his foe Ivo but never escapes his torture. His trajectory is circular, this circular movement being a characteristic of Gothic literature (and one may think again of the Gothic use of the spiral staircase), because he is constantly in movement but never makes any linear progress. ${ }^{13}$ His

I2With regard to the use of the manuscript in Walpole's novel, MacAndrews states: All this puts on notice that a mysterious world is about to be revealed.

Sentimental and Gothic novelists frequently use fictitious editors of this sort. They are more than just a means of the author to conceal his identity. The statements these "editors" put into their "prefaces" must not be taken at face value. Rather, they are the first of many signals alerting us to the kind of reading required of us. For instance, by setring the "editor" between us and the "chronicler," who is himself relaying a story and, besides, is presented as suspect, Walpole guards against our rejecting the story because of its blatant artificiality, by putting us on notice that we must follow it according to its own rules (MacAndrews 11).

13 Linda Bayer-Berenbaum considers this movement and the circular staircase motif to be central to Gothic literature: "Besides contrasting extremes, twisted convolutions in Gothic settings also extend the conception of reality. The devious and elusive 
psychological trajectory is also circular because he moves in and out of states of insanity, and even when Ivo is finally killed and Albert is reunited with Corali, he attempts to rape her in a violent insane fit for which she must attack him. At the end of the novel when Corali stabs him and he again supposedly regains his sanity, he claims to have reached the end of his moral and physical journey, cured of his emotional and psychological ailments: "-Coralí! - vaig cridar-li, i ella tota es commogué com una víctima que pressent un nou atac-. Coralí! No temis, que ja sóc curat: el meu cor, purgat de la sang endimoniada pel mal esperit, ha obert els ulls a la veritat; ni ara, ni abans, mai he estat digne de tu, però fins ara no ho he comprès; amb la mort em dons la vida" (584). ${ }^{14}$ However, at least according to the introduction by the editor, Albert had lived out his life alone, he had lost Corali and was far from cured, still displaying a weak grip with reality in his eccentricities. Albert ends the novel in an apparent death which may be symbolic; he has waged a furious war with Ivo and has won, only to discover that he has neither obtained his "trophy" (Corali), nor has he been able to escape Ivo's control, his presence haunting Albert in his relative madness until death.

One of the key characteristics of the Gothic novel is that of the contrast, the beautiful beside the hideous, the terrifying beside the hilarious. In Vayreda's novel, there exists another use of contrast, that of the materialistic (realist) world contrasted with the emotional (romantic) one of Albert. Linda Bayer-Berenbaum states that these contrasting elements must accompany each other: "Gushing sentimentality is set besides brutality, each to highlight the other" (24). In La punyalada Albert's pain and psychological torture during his desperate search for Corali is contrasted with the cold rationalism of Arbós, the head of the posse which searches for the bandits. He tries to console Albert concerning the loss of Corali with the bizarre consolation: "Sortosament que encara no éreu casats" (Vayreda 533). Albert himself is shocked by this contrast between his pure emotion and Arbós cold materialism in which even a beloved may be looked upon as a possession. Later in the novel, an increasingly deranged and hostile Albert himself witnesses another contrast and is again amazed

nature of life is reflected in the winding staircases and underground tunnels that challenge the restrictions of three-dimensional space. In their tortuous winding, they baffle our sense of direction and threaten to lead us out of the known and into the depths of another dimension" (Bayer-Berenbaum 24).

I4 The reader by now no longer believes Albert's supposed recoveries. By the end of the novel he has constantly passed through periods of relative clarity, always followed by another attack of dementia. Also, the beginning of che novel has already stated that the "chronicler" of the events, Albert himself, is an eccentric hermit. 
when Arbós' son is discovered, dead and mutilated. Now it is Arbós who is the personification of emotion and he embraces his son's mutilated and rotting corpse and must be separated from it by force before he weeps: "Dos dels seus subordinats l'obligaren a la força a desfer-se'n, fent-lo seure al marge, i mentre altres despenjaven el difunt, ell arrencà una mena de plor petit i estrany com el de qui no en sap perquè no ho ha fet mai" (54I). Here the interior contradiction which is Albert's two poles, his own brutality and sentiment, come into focus in the novel as he is the only member of the party who does not share in Arbós' grief, remembering the latter's indifference:

Qui més qui menys, plorava hom.

Tothom menys jo; menys jo, sí, que amb les entranyes regirades i fetes malbé, encara semblava trobar un principi de consol per a la meva moral pervertida amb el dolor d'aquell home a qui sempre havia trobat ferreny i eixut com les roques de Bestracà.

- Ara sabràs, cor de gel —em semblava dir-li-, ara sabràs el que és sentir l'ànima carbonitzada de dolor, patir fam i set de venjança i donar punyalades al vent! (Vayreda 542)

One of the themes of the novel is vengeance, repeated in the quote "Justícia, mai venjança" (justice, not revenge) which is inscribed on the knife which Albert buys for Corali and which she will use to defend herself from him in his insane attempt to rape her at the end of the novel. Albert has become totally obsessed with revenge and his emotions are in complete control, his reason, slowly deteriorating to the point of insanity, and this descent into madness is a traditional Gothic characteristic. The novel presents these contrasts, especially that of reason (justice) and brutality (revenge), and it is justice/reason that is supposedly favored. Uncontrolled emotions are presented throughout the novel, always as being aggressive and destructive, while the only positive emotional presentation is love tempered by reason, such as in the case of Albert's mother, and in Corali, wh,o although she loves Alber,t could still kill him if he hurt her.

One of the key characteristics of Gothic literature is the protagonist's descent, in this case Albert's psychological descent from the already ominous setting of Garrotxa as reality into his own world of total insanity. Albert's transformation into a dog is only the culmination of his descent; his descent into madness is circular, and his bouts with insanity often occur during solitary meditations concerning the ominous natural landscape. William Patrick Day, in his study of Gothic literature, proposes the characteristic descent of the protagonist into an underworld through a process of dreaming or doubling until the character becomes the very embodiment of its own torture: "The Gothic fantasy is a rable of identity fragmented and 
destroyed beyond repair, a fable of the impossibility of identity" (6). ${ }^{15}$ In La punyalada both Albert and Corali lose their identities, never to be regained. She is no longer considered to be an appropriate fiancée because of her long captivity under the bandits, and Albert descends into a madman that first terrifies locals, then becomes the wolf and later Rafel's dog, and finally he is the hermit who wrote the manuscript. Albert as he is at the start of the story does indeed die, at least symbolically in the "res més" at the end of the novel. He has descended into a personal hell and cannot recover his original identity, or at least the character who is named Albert at the beginning of the memoir's narration will never again be realized, substituted for the hermit who does not even remotely resemble him. The open ending of the novel, however, brings a new interpretation to the Gothic idea of loss of identity. Even as Albert declares the end of his existence, the edited version which Marià Vayreda left at his death questions the idea of identity. Albert seemingly exists after the "res més", yet he is obviously not the same person which presents the theme of the impact of events on identity. The fact that Vayreda's other novel Sang nova is precisely a study of Catalan identity and a call to its renovation and rebirth, one may suspect that Vayreda had planned to rewrite the ending as to unite the death of one version of Albert with the symbolic birth of the hermit.

Death and decay abound in Gothic fiction. The second half of $\mathrm{La}$ punyalada alternately presents the progressive psychological decay of Albert and the deaths of the victims of the bandits, as well as their own deaths when they are ambushed. The role of death is a central

Is Day traces the complete descent and defeat of the protagonist in what could easily be a summary of Albert's own journey into his personal hell:

The Gothic fantasy employs many of the motifs and archetypes of the romance, particularly, the narrative pattern that Frye calls "the theme of descent," which portrays the movement of hero or heroine from a higher to a lower world, from Eden or the natural world to the underworld, in search of lost identity. The underworld is a place of terror and cruelty, "demonized," as Frye calls it. The romance protagonist often descends into the underworld through the medium of a dream or through a process of doubling. Then he undergoes a series of transformations and ritual sufferings that lead to the discovery or recovery of his identity and to either a return to the world left behind or the establishment of a new paradise. In the Gothic fantasy, however, there is no ascent from the underworld, nor is a new Eden established there. The hero never recovers his true identity. Once in the demonic underworld he becomes subject to endless transformation and metamorphosis, his identity permanently and completely fragmented in a world of cruelty and terror. It seems that the only escape from the Gothic world is death, but even this release is an illusion. In the Gothic fantasy, death is neither an escape nor a door through which one can pass to achieve a final humanity. In death, the protagonist becomes, not simply a victim, but fully part of what tormented him. Death releases the protagonist from the last vestiges of human identity, and he becomes the embodiment of cruelty and terror (Day 7). 
theme in the studies mentioned here on the Gothic, and death is a central theme in the Gothic novel, in part because the works themselves focus on heightened perceptions as a key to perceiving the rest of reality that Gothic literature attempts to reveal. ${ }^{16}$ While the use of death and the graphic presentation will be presented later in their relation to modern art-horror, the necrophilic type is considered by Linda BayerBerenbaum to be another of Gothic literature's prevalent themes, aberrant sexuality being an element in both modern and traditional Gothic works, and is described thus: "the "lover of death" who sees the world in two categories: the powerful and the weak, the tyrant and the victim, the killer and the killed...The Gothic proclivities for death and decay, power, extremism, sharp contrasts, and repressed material are all implicated here in the necrophilic perversion" (42). Albert's bizarre fixation on corpses in the novel is, for the most part, presented as a fascination with the horrible, or, in the case of the bandits' bodies, a manner in which to quench his thirst for revenge. Upon the death of Albert's closest friend Pep, his view of the corpse changes drastically. In this case he is attracted to the beauty of the corpse, and ends thoroughly envious of Pep, wishing to change places with the corpse, indeed become the corpse so as to be a sexual corpse-object for Coralí:

La seva fesomia de noi bondadós s'havia fet més interessant, fins bonica: sí, bonica com no l'havia trobada mai, velada per la pallidesa de la mort... Involuntàriament, va venir-me al pensament que si la Corali, que tant li bromejava de les cames i les orelles i la nou del coll, l'hagués vist en aquell moment, l'hauria trobat bell, com dignificat pel sacrifici de la vida que per ella havia fet; i aquest prestigi pòstum despertà en el fons del meu cor com un lleuger sentiment de gelosia i d'enveja. Què no hauria donat de veure'm en el seu cas, acabats els sofriments i oferint als ulls de la meva estimada Pespectacle sagnant del meu cos sense vida embellit per la gloriola d'una mort heroica!" (545).

Albert discovers physical beauty in his friend's corpse, a beauty never found in life, and his ironic envy of death returns to the Gothic theme of the protagonist's wish to escape the Gothic hell through death, as well as death's very beauty. Also, Albert's obsession with jealousy has become such that he must continue in his transformations because he can no longer find any sort of satisfaction in his current incarnation. In his descent, he even wishes to be transformed into a beautiful corpse to be worshiped sexually and heroically. Albert

16 Linda Bayer-Berenbaum analyzes the importance of terror in the Gothic nove] thus: "Despite the lure of death, that black-draped phantom in his menacing chariot does evoke a sense of terror. Terror is a primary Gothic ingredient not only because it is a reaction to threat but also because of its own physiological quality. 'The terrified person, and the reader by identification, becomes alert suddenly (Baycr-Berenbaum 31). 
himself wishes to become the victim of the gruesome act of violence, the object of pity for the implied reader and, more immediately, for Coralí. Albert wishes to be the same object of sympathy that is found in the attractive victims of violence in the modern horror film, the same victims with whom the audience shares terror and who, in the moment of their demise, are united with the spectator, their death being the moment in which they are no longer alone, their emotions surpassing the text itself. This is perhaps the impulse that leads him to attempt to rape Coralí (rape also being a theme in Gothic literature) after he has bought her a knife and specifically ordered her to kill him should ever try to harm her.

Albert buys Corali the knife so that she may protect herself against Ivo. Symbolically, the knife represents the two lovers with its inscription "Justice, not revenge", she always symbolizing an adherence to justice and Albert an obsession with revenge. Ironically, this same knife is used upon him at the end of the novel, and he himself had earlier told her to plunge it deep into the heart of any violator of her honor, and even deeper into the heart should the offender be Albert himself: "Si fos jo que anés contra llei, més a fons encara" (5I4). Albert is obsessed with death throughout the novel, but this obsession is key in Gothic literature. It is the actual presentation of the act of death itself and the natural decay of the corpse that shall demonstrate this novel's approaching the pure work of terror or horror, especially modern slasher narration, be it film or literature.

Upon discussing horror literature or literature of terror, one must attempt to distinguish between the two. However, in studies on horror and terror in film and literature, including Noël Carroll's The Philosophy of Horror, Kirk J. Scheider's Horror and the Holy, Joseph Grixti's Terrors of Uncertainty, and Terry Heller's The Delights of Terror, the same classic works are discussed as in works concerning the Gothic novel, especially Bram Stoker's Dracula and Mary Shelley's Frankenstein. The works of Edgar Allen Poe are also mentioned, when not studied in detail, as is Henry James' The Turn of the Screw, again all mentioned in Gothic studies. Wolfgang Kayser considers the tale of terror to be a development which followed both the horror story and the Gothic novel and when speaking of both Poe's and E.T.A. Hoffman's stories, when he states that: "Nor must one forget that neither of the two masters invented the tale of terror. They had forerunners, and found the magazines of their day replete with all sorts of horror stories. The way for the genre was especially paved by the Gothic novel" (Kayser 76). It is important here to fix upon some basic elements which cause the reader (at least the implied reader) to be horrified or terrified and to have a rough working definition of this fear-inspiring art to utilize when discussing La punyalada. 
Julia Kristeva in Powers of Horror identifies at least two of the elements which cause abject horror: death and decay. Both elements are present throughout the novel and the use of rotting flesh and its stench to achieve a feeling of horror on the part of the reader echoes the description of decay in Kristeva's work. Even more than the visual effect of decay is its smell which becomes a symbol of death or the fate of the body after death.17 Fear in the face of decay is the fear of contamination, that the decay will attack the living as it has attacked the dead. Proximity to decay destroys the living's feeling of distance from death by showing the body to be only organic, the spiritual world is invisible while the body's destruction attacks both the visual and olfactory senses. Kristeva applies this fear of decay to that which most terrifies the living: "And yet it is the human corpse that occasions the greatest concentration of abjection and fascination" (149).

Besides the descriptions of mutilations at the beginning of the novel, the next description which is an example of horror (or horrorinspiring) occurs when Corali is kidnapped and the mill burned. The descriptions of the burnt, stinking bodies, barely dead, are intermingled with the very term "horror":

Enmig de la fetor de robes i llana cremada, començaren a pujar de la cuina unes bafarades de carn fregida que regirava les entranyes. Convençut, amb horror, que allò era algun cos humà que es consumia, $i$, no essent possible arribar-hi per la escala, que era una brasa, vaig escalar la finestra.

I tal si cremava: era el mosso que jeia estirat damunt del postam esfondrat, sostenint-se sols per una biga que, com a més gruixuda, no havia cedit encara; tot el seu cap era ja mig consumit per les flames i els humors del cos regantellaven encesos a la quadra de baix. Em retirava horroritzat...(517).

Here Albert describes his own horror, and the details provided are given to provoke horror on the part of the reader. Here is the very moment of decay, of mutilation of the body, and this is only the beginning of $L a$ punyalada's voyage into horror. If Albert's reaction to his friend Pep's corpse was one of a necrophilic type fascination, his reaction to the others in the novel will be seen to be that of either monstrous satisfaction brought about by his need for revenge, or total a revulsion that the work of horror provokes.

17 Kristeva's description of decay is the following:

Decay: privileged place of the mingling, of the contamination of life by death, of begetting and of ending. Its high point may perhaps be found in an apocalyptic description of the earth rotted away by maggots of the scholar Courtial des Pereires: the scientific experiments of the inventor of Genitron, far from perpetuating life, succeed only in transforming a food, potatoes, into an unbearable stench ("corpses or potatoes"), and in rotting the very stones (Kristeva 149). 
One of the most typical examples of horror-inspiring decay (that of the corpse) in the novel is the case of Arbós'son, Arbosset. As the posse passes through a field looking for the hiding bandits, they come upon a scarecrow, but upon closer inspection, Albert and his companions are shocked to suddenly discover that the scarecrow is actually the mutilated corpse of the son of their leader:

La burla era més luctuosa, ja que era el propi Arbosset el penjat a la picota. Fermat pels braços i pel coll a la creua, les cames li penjaven esllanguides sota un ventre enorme, inflat pels humors en descomposició. El clàssic barret de copa s'aguantava a plom sobre el cap, caigut de cairell sobre el muscle. Amb les galtes i el nas penjant-li cap a un costat, els ulls mig oberts i guerxos, la boca mig badada i torta, ensenyant les dents d'entre les quals, per a més befa, penjava una grossa pipa, feia la ganyota més dolorosament estrafolària que imaginar-se pugui i l'espectacle era, en conjunt, d'un ridícul tan estranyament tètric, que feia venir tremolament de cames 1 regirava ies entranyes (54I).

The most important quality here is the bizarre combination of the ghastly with the comical. The comical scarecrow is transformed into the gruesome rotting corpse. It is this gruesome type of presentation that brings this work into the realm of horror. Noell Carroll in The Philosophy of Horror sets very specific criteria for the work of horror. He decides that there must be a monster, and that it must attack a woman. However, while Psycho is not included as a work of horror in his work for the reason that there is no monster in the film, the critic must account for the reasons that Hitchcocks's masterpiece is almost universally considered a horror film: "For even if Norman Bates is not a monster technically speaking, he does begin to approximate the central features of art-horror as I have developed them. That a madman with a butcher knife is threatening needs no comment. But, as well, Norman Bates, in virtue of his psychosis, resembles the impure beings at the core of the concept of art-horror" (Carroll 39). Ivo is not technically speaking a monster either, and yet he and the bandits commit a type of mutilation of bodies that resembles that seen in modern horror films (one may think of Halloween and Friday the $\left.{ }^{\mathrm{I}} \mathrm{th}\right) \mathrm{.}^{18}$ While the absence of the supernatural monster may at first be problematic in the assessment of the element of horror in the novel, there is no monster in Hitchcock's Vertigo either, yet a monstrous quality and the monster itself may be metaphorical according to Kirk $\mathrm{J}$. Schneider in his study Horror and the Holy: "Although Vertigo

18 Carroll also has a place for these two films and the presentation in each of an escalation in the creative presentation of murders and of bizarrely mutilated corpses. This same scale, from simply stinking, burning corpses, to creative mutilation, on the part of the bandits and on the 'evil' environment itself, follows the same escalating trajectory in La punyalada. 
involves ghosts and monstrosities, they are much more metaphorical than in the previous stories we have discussed. The horrific core of the film, however, is completely consistent with the previous works. It concerns the deviation from (and ultimately the contradiction of) conventional reality (86). Ivo, the bandits in their evildoing, Albert as a wolf and devouring dog, and the bizarre deaths of the bandits all show the novel to share this "horrific core" for the work is full of monstrosities.

The need for a woman victim, and indeed victimization in general, is discussed in all of the works cited here regarding the Gothic novel, the tale of terror, and art-horror, and in La punyalada. Corali is the obvious victim, kidnapped, almost certainly raped, her family murdered, and indeed considered "dead" in her supposed dishonor by the posse. However, she is presented from the beginning of the novel not as the screaming, helpless victim, but powerful and almost animalistic in her fierceness and strength to the end of the work when she defends herself against Albert, stabbing him. Joseph Grixti in Terrors of Uncertainty studies the underlying social implications for the production and popularity of certain types of horror fiction. $\mathrm{He}$ proposes that the popularity of films in which liberated women are attacked in the early 1970 's reflected society's reaction to the woman's movement, and he then expands upon his theory of art-horror popularity in his discussion of the critic J.B. Twitchell's own theories of horror:

At times of gradual cultural shifts, Twitchell argues, "people need some "object" toward which they can direct their anxieties". The implications of this phenomenon when it expresses itself in works of horror fiction like the ones just mentioned are complex and potentially regressive - particularly when they endorse and compound stereotypical and ideologically motivated images like those of non-domesticated women being punished (23).

While it is possible that Corali is punished for her strength of character in the novel (and it is at least insinuated that it is her fate for being flirtatious earlier with Ivo), the entire town's punishment has already been foretold by Mossèn Jeroni in his sermon. If the novel must create an environment of horror, it is to punish the populace's own sinfulness. They have polluted their own reality and must accept their fate because the bandits, as stated by the priest, are attracted to them. The characters themselves are the impurity that is one of the basic requirements of the horror genre.

However, there may be another message here, beyond that of chastising a sinful "here and now" common in works steeped in the nostalgic longing for a purer past. Grixti discusses the socio-political messages behind modern horror films, linking alien invasion movies 
to the Cold War, works of demonic possession and demon children to the topics of abortion, diminishing global resources, and tying violent youth films, such as $A$ Clockwork Orange, to the youth movements and anti-Vietnam protests of the 1960's and 1970's (Grixti 26). Considering the fact that the only other novel written by Mariá Vayreda is a thesis novel on the importance of Catalan nationalism written with a strong political didactic agenda, a theme or intent more socially applicable than simply horrifying the reader may perhaps be found to be transmitted, if subtly, in La punyalada.

Arbosset is brutally mutilated when he is sent to seek help for the posse from government guardsmen, and the disinterest of the Spanish central government regarding the plight of the Catalan mountainous regions is mentioned in the novel. What is more effective, even more than the obvious and overt cry for Catalan nationalism in Sang nova, to call for a movement to Catalan autonomy than to show the public the terrifying consequences of distant rule? Vayreda criticized the very idea of "justice" in Spain in his political articles and one of recurring concerns is the "Altra plaga que amenaça" or the overabundance of students in military science, far beyond the national need. It is no coincidence that this particular article, from 1892, constantly utilizes the terms "amenaça" and "plaga social". What are the trabucaires, but former soldiers and what do they endanger, agricultural and small industrial production, the same victims that Vayreda believes this plague of military cadets poses to his society (Obres 594) Alessandro Manzoni presented the same idea, including the fear of the innocents at the hands of local bandits, the kidnapping and near rape of a young woman (Lucia), and the quest to save her by her fiancé Renzo, in I promessi sposi. Manzoni shared a nationalist ideslogy and the underlying didactic theme is the need to liberate Italy from a French military, if not a French ideology of federalist government.

The hidden enemy in this work, the catalyst which sets the evil forces at work, is indeed the villager's sinfulness, but part of their sinfulness is their lack of political convictions, their lack of vision with regard to the dangers the former soldiers pose, and their surrender to murderous violence when they should band together and seek strength to protect economic interests against evil, coming together as a united (and national) whole.

TIMOTHY McGOVERN UNIVERSITY OF CALIFORNIA, SANTA BARBARA 


\section{WORKS CITED}

BAKHTIN, M.M. The Dialogic Imagination. Trans. Caryl Emerson and Michael Holquist. Ed. Michael Holquist. Austin: University of Texas Press, 1996.

BAYER-BERENBAUM, Linda. The Gothic Imagination. London and Toronto: Associated University Presses, 1982.

CARROLl, Noel, The Philosophy of Horror ar Paradoxes of the Heart.

New York: Routledge, 1990.

CASElLAS, Raimon, Narrativa. Barcelona: Edicions 62, ig88.

CATALÀ, Víctor. Obres completes. Barcelona: Editorial Selecta, I95I.

DAY, William Patrick. In the Circles of Fear and Desire. Chicago: The University of Chicago Press, 1985.

FreUD, Sigmund. Totem and Taboo. Trans. James Strachey. New York: W. W. Norton, 1989.

Heller, Terry. The Delights of Terror. Chicago: University of Illinois Press, 1987.

KAYSER, Wolfgang. The Grotesque in Art and Literature. Trans. Ulrich Weisstein. Gloucester, MA: Peter Smith, 1968.

Kristeva, Julia. Powers of Horror. Trans. Lleon S. Roudiez. New York: Columbia University Press, 1982.

MACANDREw, Elizabeth. The Gothic Tradition in Fiction. New York: Columbia University Press: 1979.

ManZonI, Alessandro. I promessi sposi. Milan: Oscar Mondadori, 1990. MARFANY, Joan Lluis. Aspectes del modernisme. Barcelona: Curial, 1975. Mullahy, Patrick. Oedipus Myth and Complex. New York: Hermitage, 1948 .

RiQuer, Martín de. Història de la literatura catalana. Vol. VII. Barcelona: Editorial Ariel, 1986.

SCHNEIDER, Kirk J. Horror and the Holy. Chicago: Open Court, 1993. Serrahima, Maurici. Dotze mestres. Barcelona: Edicions Destino, 1972. SIEBERS, Tobin. The Romantic Fantastic. Ithaca, NY: Cornell University Press, 1984.

TODOROV, Tzvetan. The Fantastic: A Structural Approach to a Literary Genre. Trans. Richard Howard. Ithaca, NY: Cornell University Press, 1995.

VAYREDA, Marià. Obres completes. Barcelona: Editorial Selecta, 1984. 